\section{Industrial links still face opposition in Japan's universities}

Asako Saegusa

Japan has traditionally had poor links between universities and industry. The government hopes to change this. But its efforts face a daunting challenge in the need to transform deeply engrained attitudes.

[TOKYO] Japan's Ministry of International Trade and Industry (MITI) announced last week that it is setting up a ¥50 billion (US\$427 million) fund to support up to 1,000 'venture businesses' a year, including some based at universities. The move is part of the government's effort to promote the commercial application of university research by improving links between universities and industry.

But substantial changes in attitude are required for such endeavours to succeed. For example, the current law on civil servants forbids researchers at national universities from getting involved with profit-making activities and carrying out research at industrial laboratories.

In addition, Japanese universities have a conservative attitude towards such activities. Researchers point out that making inventions and obtaining patents do not earn them any credit in institutions that still see the production of scientific papers as their top priority.

Since a law promoting collaboration between universities and industry was passed in May, both the Ministry of Education, Science, Sports and Culture (Monbusho) and MITI have actively backed programmes to set up technology liaison offices (TLOs) and venture businesses at Japanese universities (see Nature 390, 105; 1997).

TLOs have already been established at some national universities, including Tokyo University and Tsukuba University. They are intended to help draw up contracts for collaboration with industrial laboratories and to advise on the commercial exploitation of inventions made by university researchers.

Monbusho has also been backing Venture Business Laboratories (VBLs), a programme begun in 1996 to develop closer ties between academic research and the industrial community. VBLs have so far been set up at 24 national universities, providing laboratories for joint research projects and training programmes for students and researchers who wish to set up their own small companies to commercialize university research.

The government has already started changing the regulations on university fund-

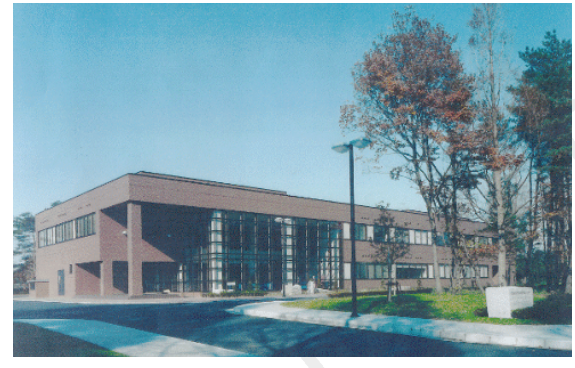

Venture capital: Tsukuba University is investing in new companies that find uses for research.

ing to encourage such developments. For example, Monbusho has relaxed its restrictions on universities applying for funds from other government sources, such as MITI. Another change allows private investors to lend money to universities creating start-up companies based on their scientific discoveries; private funding to national universities was previously restricted to research grants, scholarships and donations.

But restrictions on university staff mean that new ventures, such as the Centre for Advanced Science and Technology Incubation (CASTI), a limited holding company set up in July by professors from Tokyo University's Research Centre for Advanced Science and Technology (RCAST), have had to recruit staff from outside the university.

CASTI is intended to evaluate the marketability of inventions by university researchers, draft patent applications, and sell patent rights to private companies (see Nature 391, 622; 1998). It is the first unit set up by a Japanese university to promote the commercial exploitation of its inventions. Some of the royalties from sales of the patents will go to the inventor, with the rest being paid into RCAST's research budget.

Because RCAST belongs to a university, it will not be able to take an active role in the business or hold patent rights to inventions made at the institute, and the professors who set up RCAST and control its work are not allowed to receive any profits, as this would infringe the civil-service law.

The conservativism of Japanese universities is reflected in the fact that they produce very few patents. In 1994, for example, only
124 out of 351,300 patents filed internationally were from universities, and just seven out of 215,400 domestic patents filed in 1996 were from Tokyo University.

According to a recent survey by Nihon Keizai Shinbun (Nikkei), a daily financial newspaper, only 30 per cent of universities surveyed expressed support for their academic staff's involvement in business activities. "Given the current legal restrictions, national universities are still wary about getting involved in business activities," says a professor from RCAST. "There is an inevitable conflict between the 'intellectual community', which strongly believes that universities should have nothing to do with profit-making activities, and businessminded academics, who are keen to change such an attitude."

The survey also showed that most universities are reluctant to provide financial support for new venture businesses, and more than two thirds said they do not intend to create new funds to support such activities.

An exception to this is Tsukuba University. Together with JAFCO, Japan's largest venture-capital company, it has set up a ¥1 billion fund to invest in venture businesses.

Tamon Inoue, professor in engineering at Tsukuba University and head of its VBL, says it will not be easy to break the conservative attitude of universities towards the creation of new businesses, or to encourage students to become entrepreneurs.

Furthermore, with the current economic turmoil, small high-tech companies are struggling to survive, as banks and private investors are reluctant to lend and invest money. "University students still hold firmly to the idea of lifetime employment, and joining or setting up venture businesses seems to be out of their scope," says Inoue.

$\mathrm{He}$ also points out that research at universities rarely lends itself to commercial application. "The focus of industrial research and university research are fundamentally different," he says. "For businesses to flourish from universities, researchers will need carry out 'useful' research that could bring profit to the university."

However, while researchers keen to see more collaboration between universities and industry are calling for a more flexible system that gives them more freedom, not all support the government's proposal to transform such universities into semiautonomous institutions (see Nature 395, 730; 1998).

They accept that more autonomy would provide better opportunities for new arrangements with industry to thrive. But it is uncertain whether the new system would free university researchers from civil-service rules. Many researchers say the reforms should be carried out slowly, as a quick transformation could throw the universities' management systems into turmoil. 